Univerzitet u Beču, Institut za slavistiku, Beč, Austrija

DOI 10.5937/kultura1338075K

UDK 77.01:82.0

821.163.42.09-94 Вркљан И.

821.163.42.09-31 Чорак Ж.

821.163.42.09-31 Угрешић Д.

originalan naučni rad

\title{
MEDIJALNAGLOBALLACIJA
}

Sažetak: Polazeći od uzajamnih veza dvaju medija (fotografije i književnosti), prilog pokušava pokazati kako se sveopći procesi medijalne globalizacije konkretno reflektiraju na estetske činjenice.

Ključne riječi: medij, književnost, fotografija, Vrkljan, Čorak, Ugrešić

Otkrićem $^{1}$ novih medija ${ }^{2}$, počinje i nova era u umjetnosti. Pluralizacijom medijskih mogućnosti promatranja, kao i vjernim prikazivanjem virtualnih realnosti i simulacija, novi su mediji promijenili naše spoznajne metode, načine istraživanja i oblike komunikacije, ali i naša estetska poimanja, načine opažanja i osjećaje, te odredili svakodnevni život. Omiljeni i svima dostupni, novi su načini komuniciranja pridonijeli tomu da se poznato doživljava kao strano, a strano kao poznato, blisko kao daleko,

1 Tekst je nastao u okviru habilitacijskog projekta (Das literarische Pendel. Drei Schriften der neueren kroatischen Prosa: die autobiographische, die märchenhafte und die mediale Schrift, Peter Lang, Frankfurt am Main, 2012) Instituta za slavistiku Bečkog sveučilišta. Ideje ili dijelovi teksta već su bili objavljeni i u slijedećim periodikama: Fotografija kao izričaj recentne hrvatske književnosti, u: Postmodernizam, iskustva jezika u hrvatskoj književnosti i umjetnosti, Zbornik radova II. znastvenog skupa s međunarodnim sudjelovanjem, (izd.) Bošnjak B., Bošnjak V., Milanja C. i Stojević M., Altagama, Zagreb; Zwei Medien - Eine Ausdrucksweise. Literatur und Photographie in der postmodernen kroatischen Prosa, in: Wiener slawistischer Almanach, München 2011, str. 321-349.

2 Polazeći od činjenice da era novih medija započinje pronalaskom „tehničkog reproduciranja“ (usp. Benjamin W., Das Kunstwerk im Zeitalter seiner technischen Reproduzierbarkeit, Frankfurt am Main 1963, str. 7-65) u ovom radu pronalazak fotografije (1839) i njezino širenje kao tehnike, a potom kao umjetnosti, smatrat će se početkom i prekretnicom prema novom kulturnom i umjetničkom (medijalnom) dobu. Kako i Faulstich medij fotografije u svome razvoju medija označuje kao svojevrstan „međumedij“, koji je prvotno pripadao više tiskanim te potom elektroničkim medijima, a danas ga susrećemo u digitalnom obliku (usp. Faulstich W., Medienwissenschaft, Stuttgart 2004, str. 12-15), njegova će klasifikacija u nastavku činiti širok okvir za specifikaciju medijskoga pisma o kojemu je ovdje riječ. 


\section{BERNARDA KATUŠIĆ}

a daleko kao blisko. S novim medijima temeljito se promijenio i tradicionalni bipolarni odnos stvarnosti i fikcije. U dobu novih medija više nije moguće pouzdano razlikovati činjenice i fikciju, ono što se može predočiti i ono što se može reći, istinito i lažno, bitak i privid. Pojavom novih medija nastaje novi oblik konkurencije književnosti i drugim oblicima umjetnosti, čime ne samo da postaju upitni status i izvorna funkcija pojedinih medija, nego su i estetski načini izražavanja svakoga od njih odredivi tek njihovim „uzajamnim osvjetljivanjem“3. Kako u tom kontekstu više nije moguće govoriti o osebujnosti pojedinog medija bez odnosa s drugim medijima, aktualno stanje u umjetnosti moguće je dovesti u vezu s općim procesom globalizacije i označiti ga kao svojevrsnu medijalnu globalizaciju. Kako se navedena medijalna širenja i prožimanja konkretno reflektiraju na estetske činjenice u daljnjem ćemo pokušati pokazati na međusobnom prožimanju medija fotografije i umjetnosti.

\section{Nestalni oblik}

Koliko god je očito da više nema nijednog područja suvremenog života koji ne bi bio pod utjecajem medija, odnosno da pristup svijetu gotovo nije moguć bez medijalnog posredništva, čini se da u aktualnome teorijskom diskursu na pitanje što je „medij“, kako ga je moguće definirati per se, još ni izdaleka nije odgovoreno. Jednom označen kao forma, drugi put kao „,moguća forma“"4, jednom kao tehnički sustav znakova koji prenosi neku poruku, drugi put kao poruka sama ${ }^{5}$, jednom kao puko materijalno tehničko sredstvo, drugi put kao sredstvo manipulacije i moći ${ }^{6}$, jednom kao običan svakodnevni predmet poput naočala, vilice ili radija, ${ }^{7}$ drugi put kao bit svijeta, istina, ljubav, razbor, narod, sumnja, iskrenost - da spomenemo samo neke od definicija. Medij se dakle pokazuje kao nestalna forma, kao predmet s mnogim fasetama i gotovo neograničenim mogućnostima primjene. ${ }^{8}$

3 Usp. Zima V. P., Ästhetik, Wissenschaft und ,wechselseitige Erhellung der Künste“, Einleitung, u: Literatur intermedial. Musik-Malerei-Photographie - Film, priredio Zima V. P., Darmstadt 1995, str. 1-31.

4 Paech J., Intermedialität. Mediales Differenzial und transformative Figurationen, u. Intermedialität, Theorie und Praxis eines interdisziplinären Forschungsgebietes, priredio Helbig J., Berlin 1998, str. 23.

5 Usp. McLuhan M., The medium is the massage, New York 1967.

6 Baudry J. L., Ideologische Effekte erzeugt vom Basisapparat, u: Der kinematographische Apparat, Geschichte und Gegenwart einer interdisziplinären Debatte, priredio Riesinger R. F., Münster 2003, str. 27-41.

7 McLuhan M., Die magischen Kanäle, Düsseldorf/Wien 1968.

8 Usp. Schanze H., Vorwort, u: Medientheorie, Medienwissenschaft, Metzler Lexikon, priredio Schanze H., Stuttgart 2002, str. 5-8, i Biti V., Pojmovnik suvremene književne teorije, Zagreb 1997, str. 213-217. 


\section{BERNARDA KATUŠIĆ}

Iako je iz navedenog evidentno da se terminološka nedosljednost u uporabi pojma medij u suvremenoj teoriji medija ne može lako riješiti, mišljenja smo da ga je moguće pobliže odrediti naznači li se razlika između znaka i medija, odnosno odgovori li se na pitanje: je li medij puki znak ili ipak nešto više?

Naime medij je, poput znaka, istodobno prenositelj informacija i pogleda na svijet. Bez povijesne integracije oba sustava posredovanja, iako svaki na svoj način, valja tumačiti kao stanovitu „reprezentaciju nečega nečim drugim“, kao sliku stvarnosti koja se uvijek odnosi na izvjestitelje realnoga svijeta. Dok sustav znakova počiva na apstraktnome odnosu prema stvarnosti i uvijek ostaje zatvoren u trokutu (površina znaka - sadržaj znaka - referent), medijski sustav pokazuje znatno širi odnos prema stvarnosti. U usporedbi sa znakom, koji uvijek fungira kao nosač stanovite referencije, medij je uvijek nešto „više“ od pukog materijalnoga sredstva i posrednika: znak posreduje isječak stvarnosti, a medij (pre)oblikuje stvarnost po sebi; znak prenosi određenu obavijest, a medij inscenira obavijesni događaj; znak šalje poruku, a medij oblikuje pogled na svijet. Medijski je sustav znatno složenije organizirana posrednička instancija od znakovnoga sustava. U usporedbi sa znakom, koji je fokusiran na to da nešto reprezentira, u mediju se uvijek nešto inscenira. Medij je institucionalizirani pogon koji u sebi sadrži ne samo veći odslik referencije, otvarajući se tako svijetu šire i dublje, nego zahtijeva i mnogoslojnu i rafiniranu organizacijsku inscenaciju. Komunikacijski raster medija ne počiva samo na tehničkome kodnom sustavu - to je „mreža socijalnih konvencija, tehničkih pretpostavki i dispozicija uobrazilje, interdisciplinarno ispisivog sjecišta psihoanalize, estetike medija, sociologije i povijesti tehnike". U usporedbi sa znakovnim sustavom koji funkcionira kao tehnički kanal ili formalni sustav, kod medijskoga sustava posrijedi je složena tehnička i socijalna organizacija, izdiferenciran posrednički uređaj koji se sastoji iz raznih latentnih i često ,,nevidljivih" mehanizama i podsustava, kao što su znanost, politika, tržište, kultura, nacija, država itd., i koji djeluje na raznim razinama.

\section{Dva medija - jedan način izražavanja: fotografija i književnost}

Poetološke zakonitosti fotografske umjetnosti, utemeljene ponajprije na razlikovanju ljudskoga oka i oka kamere, djeluju na presjecištu dvaju posredničkih sustava, sustavu znakova i sustavu medija, kao i dvaju poimanja fikcije - tradicijskog, koje

9 Usp. Lommel M., Dispositiv, u: Medientheorie, Medienwissenschaft, Metzler Lexikon, priredio Schanze H., Stuttgart 2002, str. 66. 
fikciju shvaća kao pol suprotan stvarnosti, i medijalnog, koje fikciju poima kao nultu točku spram stvarnosti. Način na koji stvarna činjenica postaje estetskom u fotografskom je mediju, kao ni u jednom drugom, istodobno zamagljen i transparentan. Naime, ni u kojem drugom mediju odnos stvarnosti i fikcije nije istodobno proziran i nepropusan, ni u kojem drugom mediju referencija nije istovremeno prezentirana $\mathrm{i}$ iskrivljena, nijedan drugi medij nije u isti mah i stvarnost i njezina simulacija. $U$ poticajnoj knjizi Svijetla komora Barthes s tim u vezi bilježi kako se „određena fotografija nikada ne može razlikovati od svoga predloška (referenta; onog što prikazuje)“"10. Prema načelu kontingencije oko kamere ovjerava dio određene predmetnosti ili pojavnosti koji aludiraju na cjelovitost i općenitost. Snimljena slika identična je „korzetu“ ili „maski“, ona je tek inscenirana i izabrana ,poza“ koja je kadra preko realnoga prizvati imaginarno. ${ }^{11}$ Fotografski zapis, poput književnoga, počiva na opoziciji dijela i cjeline, događaja i slučajnosti, smrtnoga i besmrtnoga, produkcije i reprodukcije, proizvodnje i umjetnosti, predmetnoga i imaginarnoga i operira, iako drugim sredstvima, metaforičkim postupkom fiktivnoga. Budući da je fotografija, kako je već istaknuto, jedan od prvih novih medija, moguće ju je motriti kao svojevrsnu prethodnicu i prekretnicu između „stare“ knjige i novih medija, između ere pisma i ere slike.

Moguće je izdvojiti tri kategorije kojima se pobliže opisuje navedeni metaforički postupak, svojevrsna žarišta uzajamnih veza dvaju medija (fotografije i književnosti): simulacija stvarnosti, pseudovrijeme i pojedinost.

\section{Simulacija stvarnosti}

Kako je već istaknuto, u fotografskoj se umjetnosti stvarnost istodobno prezentira $\mathrm{i}$ iskrivljuje, estetske strategije funkcioniraju prema zakonima koji stvarnost $\mathrm{u}$ isti mah preslikavaju i izobličuju, odnosno simuliraju „stvarnosnim efektima“. Stoga predstavljeno istodobno djeluje i stvarno i nestvarno, istinito i lažno. Shodno tomu u teoriji fotografije često se naglašavalo da je fotografska referencija nalik na svojevrsnu ,tautologiju“"12. S obzirom na takvu specifičnu referenciju fotografske umjetnosti, Barthes fotografiju označava kao nešto ,apsolutno posebno, kao neograničenu, slijepu i ujedno naivnu kontigenciju, kao nešto određeno, kao boginju Tiho, slučaj, susret, stvarno." 13

10 Barthes R., Die helle Kammer, Frankfurt am Main 1989, str. 13.

11 Usp. Isto, str. 21-23.

12 Usp. Derrida J., Die Tode von Roland Barthes, Berlin 1987, str. 35 i Barthes R., Die helle Kammer, Frankfurt am Main 1989, str. 13.

13 Usp. Barthes R., Die helle Kammer, Frankfurt am Main 1989, str. 12. 


\section{BERNARDA KATUŠIĆ}

Prema njemu fotografija je umjetnost koja nikada nije samo prikazani subjekt ili objekt, ali koja se isto tako nikada ne može razlikovati od svoga predloška (referenta; onoga što prikazuje). ${ }^{14}$ Sontag pak fotografiju uspoređuje sa slikarstvom i zaključuje: „Fotografija nije samo slika (kao što je to slikarsko platno), interpretacija stvarnoga, nego ujedno trag, nešto kao uzorak stvarnoga, poput otiska stopala ili mrtvačke maske"15. I Baudrillard ističe autentičnost kao jednu od ključnih osebujnosti fotomedija. Zanimljivo je da rabi sličan vokabular kao i Sontag, kako bi objasnio bit fotografije.

Svaki je fotografirani objekt samo trag koji ostaje nestankom svega ostaloga. To je gotovo savršen zločin, gotovo potpuni raspad svijeta, koji samo emitira iluziju toga ili onoga objekta, o čemu zatim slika stvara nepojmljivu zagonetku. ${ }^{16}$

Iz rečenog proizlazi da nema fotografije koju bismo mogli "odvojiti" od njezina referenta, odnosno od objekta koji je na njoj prikazan. Naime, kao što je već istaknuto, referencijalnu razinu fotografskoga medija karakterizira vizualna realizacija prikazanog objekta neizbježnom fotografskom implikacijom realnoga. Svaka je fotografija u tom smislu, kako naglašava Barthes, „potvrda sadašnjega trenutka“, produžetak geste što podsjeća na gestu maloga djeteta koje prstom upire u nešto, ona je medij koji kao da uvijek govori: ovo ovdje, točno to. ${ }^{17}$ Snimljena slika može biti i posve iracionalna konstrukcija, nešto što je neprimjereno stvarnosnim parametrima, ali u svojoj biti uvijek uključuje ranije promatrani objekt, to je uvijek vidljiva slika, nepobitan dokaz da se neki događaj uistinu tako i zbio. Stoga Sontag naglašava da je referent fotografije nužno razumjeti ne kao fakultativno stvarno, tj. sekundarnu stvarnost, nego kao „nužno“ stvarno, odnosno kao ,primarnu“ stvarnost. ${ }^{18} \mathrm{~S}$ obzirom na to da fotografija kao takva funkcionira kao certifikat stvarnosti utvrđen na zakonima vjerodostojnosti i istine, te raspolaže referentom drukčijim od svih ostalih reprezentacijskih sustava, ona ima „,nedužniji i time vjerniji odnos prema vidljivoj realnosti od drugih mimetičkih objekata" i barata sa specifično realnim simulirajući „stvarnost drugoga stupnja“19. Stoga se kao jedna od ključnih osobina fotomedija nameće uvid da ono što je snimljeno proizlazi iz realnoga, ali istodobno i klizi iz njega, čime se pri fotografiranju, kao što to naznačuje Baudrillard, događa gotovo „savršen

\footnotetext{
14 Usp. Isto, str. 13-14.

15 Sontag S., Über Fotografie, Frankfurt am Main 2002, str. 147.

16 Usp. Baudrillard J., Fotografien 1985-1998, Ausstellung, Graz 1999, str. 23.

17 Usp. Barthes R., Die helle Kammer, Frankfurt am Main 1989, str. 12.

18 Usp. Sontag S., Über Fotografie, Frankfurt am Main 2002, str. 11.

19 Usp. Isto, str. 54.
} 
zločin“20, koji realnost istodobno "vidi i spašava". Zahvaljujući takvoj tehnici, ono što je prikazano istodobno je autentično i iskrivljeno, čime se kao dominantna paradigma fotofikcije nadaje virtualnost.

Već prva razmišljanja o pjesništvu u zapadnjačkoj kulturi potvrđuju da je književnost u svojoj biti, slično kao i fotografska umjetnost, oduvijek bila u tijesnoj vezi sa stvarnošću, kao i to da je težila što vjernijem prikazu stvarnosti. Dakle pojedine stilske epohe moguće je u njihovoj dijakroniji razlikovati na temelju toga što je svaka od njih zaokupljena različitim aspektima života, a svoje konstrukte stvarnosti i istine izražava drugim sredstvima. U tom je kontekstu pojava fotografske tehnike vjerne reprodukcije stvarnosti snažno utjecala na književna sredstva, kojima se također težilo što vjernijem prikazu zbilje, kao i na njihovu promjenu. Za razliku od književne fikcije prije otkrića novih medija, koja je operirala razlikovnim estetskim kategorijama znaka i referencije, književna fikcija u medijalnom dobu, poput fotografske fikcije sa svojom reprodukcijskom tehnikom, spomenutu opreku asimilira. Kako se estetska sredstva karakteristična za fotomedij primjenjuju u književnosti, odnosno kako se proces asimilacije kategorija znaka i referencije ostvaruje u književnosti uzajamnim dodirom fotografskoga i književnoga medija, pokazat ćemo na primjeru teksta Irene Vrkljan O biografiji (1987).

\section{Književne foto-maske}

Tekst $O$ biografiji neizmijenjeno je novo izdanje dvaju ranije objavljenih proznih svezaka Svila, škare (1984) i Marina, ili o biografiji (1986). Tako nastala tekstna cjelina nije tek puki pretisak rasprodanih tekstova, izbor ili zbirka autoričinih djela, nego integralna cjelina koja upućuje na simultanu recepciju dvaju pojedinačnih tekstova i njezina cjelokupnog autobiografskoga opusa, koji obuhvaća sedam proznih svezaka.

U prvome dijelu, autobiografskome romanu Svila, škare, protagonistkinja, istodobno pripovjedačica u prvome licu i autorica, opisuje, u skladu s autobiografskim diskursom, vlastiti privatni i javni život. U fiktivnome svijetu autorica nosi svoje puno građansko ime, pripovjedačica se zove Irena Vrkljan.

Referirajući, vjerno opisanim lokalitetima, na mjesta u kojima je autorica živjela (Beograd, Zagreb) i, pripovjednim vremenom, na razdoblje od 1930 (godine autoričina rođenja) do 1984 (trenutka dovršetka teksta), u romanu se evociraju pojedinosti iz spisateljičina života, ali i razne intimne potankosti iz života drugih privatnih i javnih osoba, poput njezinih roditelja i sestara,

20 Usp. Baudrillard J., Fotografien 1985-1998, Ausstellung, Graz 1999, str. 23. 


\section{BERNARDA KATUŠIĆ}

znamenitog slikara Miljenka Stančića, njezina muža (pjesnika Zvonimira Goloba) itd.

U drugome dijelu teksta, u biografskome romanu Marina, ili o biografiji, ista narativna instancija izvješćuje istom pripovjednom tehnikom o životu poznate ruske pjesnikinje Marine Cvetajeve. Roman obiluje opširnim navodima, kako iz pjesnikinjih vlastitih djela tako i iz drugih biografija o njoj; no istodobno život Marine Cvetajeve priopćuje se preko subjektivne perspektive u prvome licu. Istim narativnim rekvizitima kao i u autobiografskom romanu Svila, škare, pripovjedačica u prvome licu, autorica Irena Vrkljan, izvješćuje o općim biografskim podacima ruske pjesnikinje i o pojedinostima i privatnim događajima iz njezina života, koje sama nije mogla doživjeti niti naći u pisanim izvorima. Subjektivnom perspektivom, netipičnom za žanr biografije, posredovanom glagolima opažanja, mišljenja i osjećanja, uspostavlja se svijet glavnoga lika. Navedenom tehnikom Irena Vrkljan potpuno se poistovjećuje s ruskom pjesnikinjom, čime relacija između autorice/pripovjedačice i protagonistkinje ne funkcionira prema klasičnome metaforičkom načelu u kojem je granica između stvarnosti i fikcije jasno povučena, nego, slično fotomediju, prema principu simulacije. Naime, premda je u tekstu jasno naznačeno da su i pripovjedačica i protagonistkinja

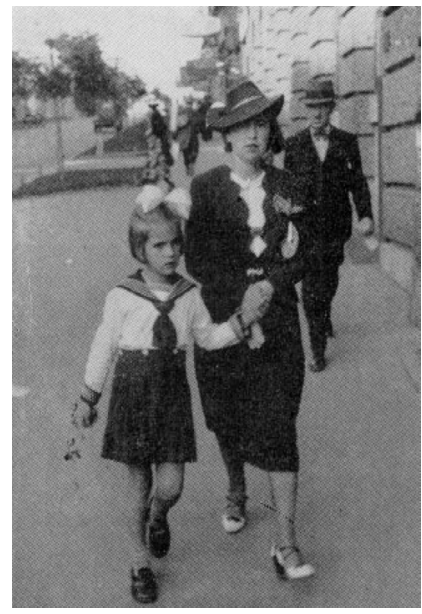

Slika 1 S mamom, Beograd. 1939. godina

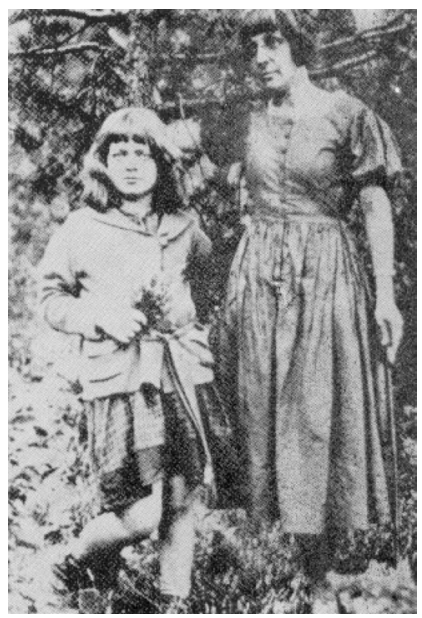

Slika 2 Marina s kćerkom Arijadnom, nedaleko od Praga, 1924. godina

„stvarne“ osobe, obje su realizirane sredstvima tipičnim za fikciju, čime je jasna granica između kategorija subjekta i objekta zamagljena, odnosno realnost je istodobno predočena i iskrivljena.

Navedeno (inter)medijalno prožimanje napose je vidljivo na onim mjestima na kojima je tekst popraćen fotografijama: u sredini teksta $O$ biografiji, između autobiografije i biografije, 
odnosno pseudoautobiografije i pseudobiografije, nalaze se, kao vizualna poveznica, fotografije iz obiteljskoga albuma obiju protagonistica s točno navedenim imenima prikazanih osoba, kao i s podacima o mjestu i vremenu nastanka (vidi sliku 1 i 2). Tako otisnute fotografije doimaju se u Vrkljaničinu fiktivnome svijetu kao svojevrsni nijemi svjedoci, kao vizualne ilustracije onoga što je verbalno već izraženo. Naime može se reći da fotografije otisnute u tekstu funkcioniraju prema sličnome načelu kao i u tekstu primijenjena pripovjedna tehnika, koja počiva na činjenicama. Slično pripovjednoj instanciji, koja ukida klasičnu granicu između kategorija subjekta i objekta, prikazane slike napuštaju svoju referenciju, čime se istodobno naznačuje i propituje suptilna granica između privida i bitka, stvarnosti i iluzije, činjenica i fikcije.

Marininu fotografiju kada je još bila dijete sada gledam kao svoju. Klica za bilo kakav opis leži više u toj odluci nego u poznavanju činjenica. (...) Naći sebe jednako je teško kao traženje djeteta Marine. Istina je jedino u samom tekstu. ${ }^{21}$

U skladu s motom koji autorica ističe na početnim stranicama romana, prema kojemu je ,istina samo u samome tekstu“, otisnute obiteljske fotografije napuštaju posredovanu referenciju, postajući književnim „maskama“, koje istodobno upućuju na ono što je prikazano i ono što je tek zamislivo. Takvim pjesnički konstruiranim foto-maskama autorica promišlja svijet kao konstrukt različitih individualnih koncepata.

\section{Pseudovrijeme}

Osebujnost fotografskog medija proizlazi i iz specifičnog estetskog tretmana kategorije vremena. Sadržaj koji fotografija posreduje odnosi se očito i na sadašnjost i na prošlost, sjećanje i zamišljanje, na realnost i na irealnost. Na fotografiji snimljena prošla realnost svojevrsna je ,pseudoprisutnost i znak odsutnosti“"22. Ono što se vidi na slici može se označiti i kao fotomontaža, ${ }^{23}$ neuravnoteženost između trenutka snimanja i trenutka promatranja, odnosno nepodudarnost između onoga što sada pred sobom možemo vidjeti i onoga što je nekoć bilo. Ono što se nalazi unutar fotografskog okvira nije primarno određeno fokusiranjem na subjekt/objekt i njegovu eksplikaciju, nego onim što je to fotografirano jednom, u konkretnom trenutku, bilo. Činom fotografiranja na poseban se način „balzamira“ ono što je prikazano i u tom se stanju može prepoznati ,poseban duh vremena i prostora, jedinstvena pojava iz bilo koje udaljenosti, bez obzira

21 Vrkljan I., O biografiji, Zagreb 1987, str. 185.

22 Usp. Sontag S., Über Fotografie, Frankfurt am Main 2002, str. 22.

23 Usp. Barthes R., Die helle Kammer, Frankfurt am Main 1989, str. 96. 


\section{BERNARDA KATUŠIĆ}

na njezinu blizinu“24. Funkcija podataka o nadnevku, kao redovita popratna pojava svake fotografije, stoga i nije samo u tomu da dokumentira trenutak nastanka snimke, nego i da signalizira bezvremenost i potakne na razmišljanje o vremenu. Točno vrijeme snimanja može se primjerice čitati i kao tajanstvena estetska šifra koja je tu da bi nam prišapnula: vrijeme je smrt. Budući da je svaka fotografija fiktivno iskustvo smrti u malome, nerijetko se u teoriji kvalificirala kao živa slika smrti, svjedočanstvo vremena, ali i potvrda o tomu da je sve prolazno. ${ }^{25}$ Zgušnjavajući prošlost u tako kompaktnom formatu, iznoseći na vidjelo vremenski raskorak koji priziva prolaznost, ovjekovječena snimka proizvodi čuđenje, potiče temeljna pitanja o vremenu, životu, o konačnosti i vječnosti. Zbog navedene vremenske pseudodimenzije fotomedij se nerijetko označavao kao ,utvara“ ${ }^{26}$ „fantom“ ”, „egzorcizam“28 ili kao „nostalgija“29.

Jednako kao u fotografskoj umjetnosti, i u književnosti oblikovanje vremena počiva na odnosu prošlosti i sadašnjosti. Za razliku od "klasične" književnosti, koja barata s vremenom tako da izvješćujući o prošlosti iz statičke, sadašnje perspektive, referira na realno vrijeme, ili koja, prikazujući davnu prošlost kao svevremenost, različitim fikcijskim strategijama realno vrijeme razara, u književnosti, prožetoj s utjecajima drugih medija, granica između sada i nekoć u isti mah je naznačena i zamagljena pa tako prikazano upućuje više na ono što je skriveno, nego na ono što je pokazano. Na koji se način navedeni, za fotomedij karakterističan postupak brisanja granice između sadašnjosti i prošlosti koristi u mediju književnosti, nastojat ćemo ilustrirati kratkom analizom proznoga djela Željke Čorak Krhotine (1991).

\section{Prazne snimke}

Prozni tekst Krhotine svojevrsni je pokušaj rekonstrukcije povijesti vlastite obitelji. Razlozi i motivi pisanja kao i moto književnoga projekta istaknuti su u uvodu: „Ali niti jedan život ne bi smio proći bez traga, kao što nije prošao bez smisla, i poradi toga na tragu radim, ovaj trag upisujem“"30.

Spisateljičin naum ostvaren je vizualnim i verbalnim sredstvima. Svaka je stranica njezina teksta poput obiteljskog albuma,

24 Benjamin W., Das Kunstwerk im Zeitalter seiner technischen Reproduzierbarkeit, Frankfurt am Main 1963, str. 82-83.

25 Usp. Barthes R., Die helle Kammer, Frankfurt am Main 1989, str. 21.

26 Usp. Isto, str. 22 i Derrida J., Recht auf Einsicht, Beč 1997, str. 6.

27 Derrida J., Die Tode von Roland Barthes, Berlin 1987, str. 17.

28 Baudrillard J., Fotografien 1985-1998, Ausstellung, Graz 1999, str. 21.

29 Usp. Sontag S., Über Fotografie, Frankfurt am Main 2002, str. 21.

30 Čorak Ž., Krhotine, Zagreb 1991, str. 61. 


\section{BERNARDA KATUŠIĆ}

popraćena fotografijom s opširnim autobiografsko-esejističkim opisom. S obzirom na to da se kratki tekstni ulomci i fotografski zapisi smjenjuju jednakomjernim ritmom, roman se može označiti kao prvi fotoroman hrvatske književnosti.

Pripovjedačica, ujedno glavni lik i autorica, istražuje na temelju različitih sačuvanih dokumenata i sjećanja vlastiti život i život članova svoje obitelji. Nastojeći što vjerodostojnije prizvati prošlost, autorica navodi točne podatke o mjestu i vremenu prikazane radnje, potkrijepljujući ih očuvanim ili kasnije snimljenim fotografijama. ${ }^{31}$ Tako su primjerice svi lokaliteti u knjizi prikazani i verbalno i slikovno (vidi sliku 3). Svi likovi referiraju na realne osobe, bliže ili daljnje članove obitelji, prijatelje, poznanike ili javne ličnosti, a predstavljeni su svojim punim građanskim imenom te kratkom ili duljom biografijom. Usto je svaki akter

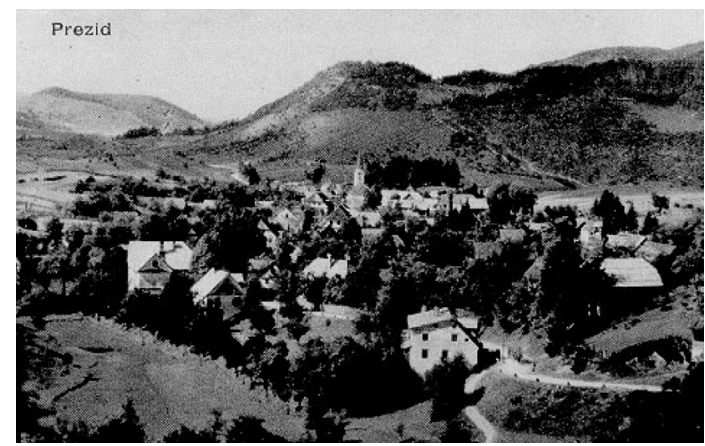

Slika 3 Prezid, Gorski Kotar. Nadmorska visina $754 \mathrm{~m}$

(Kozji vrh 928 m). Između Björndala i Vatagina

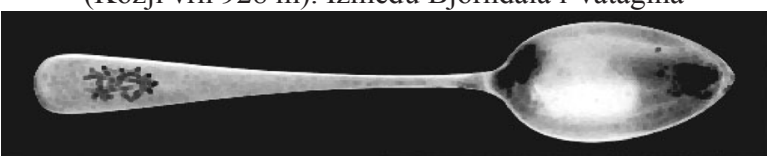

Slika 4 Totina žličica, Srebro, dužina $11 \mathrm{~cm}$. Dio garniture.

Naprijed ugraviran Totin monogram, AP. Na poleđini austrougarski žig, Dijana u peterolistu (\%800), koji je vrijedio od 26. svibnja 1866. do 22. travnja 1922. Zatim ime proizvođača (A Gigante) i još žig u obliku kupe (ili posude na stalku). Kraj XIX stoljeća. Iz Totine kuće. Na početku je mala žlica, iz male povijesti. Ništa u toj povijesti nije posebno ni značajno. Samo je obiljezena svojim slovima. I rasprostranjena je. Sva ta mala slova koja su se sačuvala štite svoju zemlju. Mrave je, naime, najteže odstrijeliti

31 Čorak opisuje funkciju fotografije u tekstu na sljedeći način: „Jedna od knjiga koja me najviše ganula u životu bila je Barthesova Svijetla komora. Zato je borba između pamćenja i zaborava (gotovo više nego između dobra i zla) ključni problem mog postojanja. Barthes pokušava povećati fotografiju da bi pronašao nepoznate pojedinosti na liku svoje pokojne majke i tako je stvarnije vratio u život. Povećana fotografija ne pokazuje, međutim, više pojedinosti nego se rastvara u raster točkica. Ona hlapi. Ta granica moći (individualnog htjenja i tehnike stoljeća) urezala mi se u živo meso. Nanin modri album s metalnim okovima bio je moj herbarij za bića. (...) Modri baršunasti Nanin album sakupio je sve ljudske biljke koje ja tako volim, a umrle su na mjestu na kojemu su se rodile. Preslagivala sam obitelj bezbroj puta, kako su rasle moje spoznaje o vremenu i zahtjevi na nj“. (Čorak Ž., Krhotine, Zagreb 1991, str. 104) 


\section{BERNARDA KATUŠIĆ}

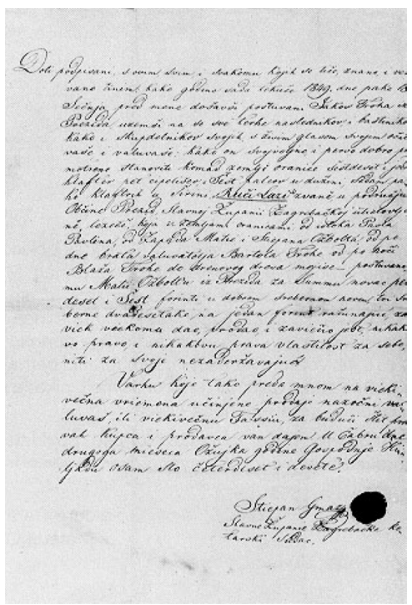

Slika 5

prikazan opširnim opisom, kao i fotografijom iz obiteljskog albuma. Mnoge su osobe okarakterizirane prilaganjem preslika osobnih dokumenata i isprava (rodni list, vjenčani list, krsni list, smrtovnica itd.) ili fotografijama njihova posjeda (kuće, gradilišta, stanovi, namještaj itd.) (vidi sliku 4 i 5).

Pritom se iscrpno nabrajanje dokumenata i izvora, te akribičan opis važnih i nevažnih predmeta - knjiga, dijelova posuđa, djedove lule, tetkina fotografskog albuma - isprepleću s usmenim predajama, vlastitim i tuđim uspomenama, istinitim i izmišljenim pričama, kao i neočuvanim dokumentima i fotografijama.

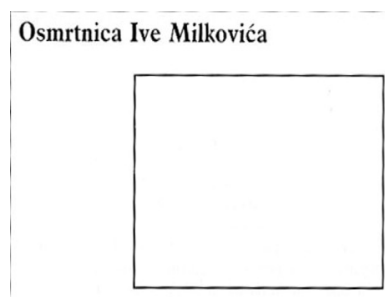

Slika 6 Osmrtnica Ive Milkovića

U ovom praznom okviru imao bi stajati jedan dokument. Dokument kojega nema, nikada ga nije bilo i nikada ga neće biti. Optužba, osuda, smrtovnica jednoga čovjeka koji nikada nije bio optužen, nikada suđen i nikada proglašen mrtvim. A ipak je jednoga dana, nakon rata odveden iz Zagreba, niti vojnik, niti član bilo koje stranke ili organizacije. Postoje oči koje su vidjele da je najprije na leđima nosio jednoga od svojih krvnika, onda kopao svoj grob i zatim u nj legao. Jednoga dana jednom budućem povijesnom pobijedniku nije više htio dati kredit. Bio je rođak pjesnika Zvonka Milkovića i političara Jakova Blaževića (“Ako nije ništa kriv, neće mu se ništa ni dogoditi”). Budući da sam ja osoba iz devetnaestog stoljeća, a taj prvi muž moje tete Julke, koji ju je odveo iz Prezida, kupio mi je moju prvu haljinicu u životu - crvenu sa sitnim bijelim točkicama - on ulazi u moju temu i pridružuje se svima onima mojima bez spomenika i bez traga: svima koji su meni dali kredit (jer očito nikada neću biti povijesni pobjednik). Tisuće života ulog su u partijama karata. Ali niti jedan život ne bi smio proći bez traga, kao što nije prošao bez smisla, i poradi toga na tragu radim, ovaj trag upisujem. 


\section{BERNARDA KATUŠIĆ}

Naime narativnome okviru kroničarsko-znanstvenoga diskursa ne suprotstavljaju se samo ,iskrivljena sjećanja“, fragmentarna „struktura krhotina“, personalizirana narativna instancija, osobna „slaba“ sjećanja i nevjerodostojne priče i sjećanja drugih, nego i fotografski zapisi, koji su, s obzirom na to da ne preslikavaju nikakav sadržaj - ,prazni“ (vidi sliku 6).

Navedenom se tehnikom tako svaki dio teksta realizira na granici između dokumenta i iluzije, u pokretu klatna između sadašnjosti i prošlosti, kronike i lirike, u ujednačenome skladu između fotografije koja prikazuje neku „realnu“ osobu ili „realni“ predmet i fotografije koja nema sadržaja.

\section{Pojedinost}

Pojedinost je uz kategoriju vremena jedina čitljiva instanca onoga što Barthes određuje kao punktum, koji je apsolutno nekodiran i nekonvencionaliziran. ${ }^{32}$ Pojedinost kao element koji "narušava prestavljenu povezanost, kako bi me prostrijelio i stvorio nekakvu novu povezanost", svojevrsna je šibica koja omogućava estetsku eksploziju, “živuća statičnost”" kojom slijepa slučajnost uhvaćena okom objektiva postaje avanturom. ${ }^{33}$ Fotografirani detalj može se stoga označiti kao magičan isječak stvarnosti realiziran raskorakom između dijela i cjeline, koji svojom transparentnom necjelovitošću aludira na neku novu, višu cjelovitost, žudi osvajanju dimenzija nepristupačnih iskustvenim osjetima, iskazivanju neiskazivog. ${ }^{34}$

Detalj je i za Benjamina bit fotografske umjetnosti, posebno poetološko sredstvo kojim je moguće prodrijeti do nesvjesnoga. Naime umjetnički oblikovana pojedinost, prema tom autoru, ne upućuje tek na puki isječak zbilje, na neposrednu sliku izvanjske stvarnosti, nego implicira novo viđenje stvarnoga. Takav način razmišljanja, zajedno s psihoanalizom najavio je početak nove ere u umjetnostima. ${ }^{35}$

Derrida također navodi detalj kao temelj fotografskog diskursa, kao jedno od najsažetijih pravila „fotogramatike“. Tumačeći u studiji Pravo na pogled zagonetnu narativnost fotografija Marie-Françoise Plissart, on odlučno ustvrđuje da je „fotografija

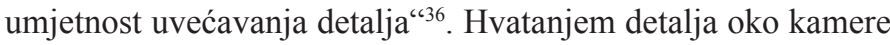

32 Pojmovnim parom studium / punktum Barthes tumači bit fotografije: Dok je studium fotografska referencija, punktum je njezin artificijelni izraz (usp. Barthes R., Die helle Kammer, Frankfurt am Main 1989, str. 35-36).

33 Usp. Isto, str. 28, 35 i 59.

34 Usp. Isto, str. 26.

35 Benjamin W., Das Kunstwerk im Zeitalter seiner technischen Reproduzierbarkeit, Frankfurt am Main 1963, str. 72.

36 Derrida J., Recht auf Einsicht, Beč 1997, str. 21. 


\section{BERNARDA KATUŠIĆ}

uvećava nevidljive i neuočljive elemente reducirajući ih na fragmente, ono ih ,slavi, idealizira, dematerijalizira, produbljuje, nabija značenjem“"37.

I Susan Sontag u teorijskim razmatranjima o fotografiji pridaje procesu fragmentariziranja i uvećavanja istaknuto mjesto, nazivajući ga „herojskim gledanjem“38. Tehnički objektiv, usredotočujući se na „krhotine, starudiju i neobične stvari“, i pritom „ništa ne isključujući“, čini vidljivim niz detalja koje nikada ne bismo vidjeli, on čini da ,živa bića postaju neživima, a neživa živima“"39.

Književnost, poput fotomedija, nastoji, reduciranjem stvarnosti, obuhvatiti svijet kao cjelinu. I ona se, vlastitim estetskim strategijama, usredotočuje na isječke stvarnosti. Kao i u fotografskoj umjetnosti, svaka pojedinost u književnoj fikciji automatski se oslobađa svoje pragmatičke funkcije zadobivajući semantički snažan poetski smisao. Svi objekti prikazani u književnome tekstu napuštaju fikcionalnim činom svoj funkcionalni uzročno-posljedični lanac i postaju svojevrsni simulacrum, koji uređuje i vodi pripovjedni subjekt. Takvom transformiranom funkcijom u tekstu, prikazani objekti iznose ,na vidjelo nešto što je u naravnome objektu nevidljivo ili što [...] ostaje nerazumljivo“40. Analizirajući predmete-detalje opisane u književnome tekstu, Calvino ih promatra kao središta estetske kreacije i naziva ih „čarobnim predmetima“.

Možemo reći da od trenutka kada se neki predmet pojavi u nekoj priči, on dobiva posebnu snagu; postaje automatski polom u magnetskome polju, čvorom u mreži nevidljivih odnosa. Simbolika, kojom neki predmet zrači, može biti više ili manje vidljiva, ali ona u priči uvijek postoji. Stoga se može reći da je svaki predmet koji postoji u nekoj pripovijesti uvijek čaroban predmet. ${ }^{41}$

Iako je svaki predmet zaogrnut fikcijom čaroban - jer ima ulogu poveznice između stvarnosti i fikcije - u kontinuitetu književnoga izražavanja postoje predmeti koji se ističu kao posebno važni instrumenti fikcije. Književni je medij svojim estetskim strategijama oduvijek operirao predmetima osobita semantičkog naboja, koji se mogu označiti kao kameni temeljci književnih konstrukcija, svojevrsni ,„̌vorovi u mreži nevidljivih odnosa““42,

\section{Usp. Isto.}

38 Sontag S., Über Fotografie, Frankfurt am Main 2002, str. 84.

39 Usp. Isto, str. 96.

40 Barthes R., Die strukturalistische Tätigkeit, u: Kursbuch 5, 1966, str. 191.

41 Calvino I., Lezioni americane. Sei proposte per il prossimo millennio, Milano 1995 , str. 41.

42 Usp. Isto, str. 91. 
takozvane „narativne relikvije“ ili „tobožnji detalji-fetiši““43. Kao fikcionalni rekviziti takvi su pojedinačni predmeti - kao primjerice prsten, kutija, zrcalo, pismo, kamen, rubac, štap, križ, medaljon sa slikom voljene osobe itd. - nerijetko ključni nositelji ne samo narativne napetosti i dinamike, nego i instrumenti koji karakteriziraju osobe i njihove odnose. Noseći pregršt različitih denotacija, ,samo polje priče“ ${ }^{\text {(44 }}$, oni poput ,goluba listono$\mathrm{s̆}^{\text {“445 }}$ zrače posebnom narativnom čarolijom, funkcioniraju kao vidljivi znakovi nevidljivih veza i događaja.

S obzirom na to da različiti žanrovi i epohe, u skladu sa svojim poetskim ustrojem, pri estetskoj kreaciji preferiraju različite tipove predmeta-detalja, na takvim bi se pojedinačnim predmetima mogao pratiti i povijesni razvitak vrsta i epoha. Pritom bi se pokazalo da im se u fikcionalnome činu uvijek pripisuje različit status, pa time i različita funkcija. Dok se u bajci rabe magični predmeti lišeni bilo kakve pragmatičke funkcije, kao što su čarobni štapić, čarobni prsten, čarobni stol, magična svjetiljka itd., realistični roman primarno operira predmetima s praktičnom funkcijom, nužnima za egzistenciju pojedinca, poput kuće, zemljišnog posjeda, namještaja, odjeće, hrane i sl., koji nerijetko upućuju na društveni status i imovinsko stanje prikazane osobe.

Suprotno tomu, u modernome se romanu akteri i njihovo djelovanje nerijetko predočuju simbolikom banalnih svakodnevnih predmeta. Među najpoznatije takve predmete-detalje u modernoj svjetskoj književnosti spadaju kolačić madeleine Marcela Prousta i smeđa čarapa Virginije Woolf. Kako se često isticalo u kritičkim promišljanjima, francuskom je književniku spomenuta slastica poslužila kao narativno sredstvo koje pokreće retrospektivno strukturirani ciklus $U$ potrazi za izgubljenim vremenom. Njezin miris budi u pripovjedaču sjećanja na djetinjstvo koja potiču na razmišljanja o ,izgubljenome vremenu“. U poglavlju knjige Mimesis naslovljenom „Smeđa čarapa“ Auerbach uzima navedeni odjevni predmet kao polazište za interpretaciju poetike Virginije Woolf. Iz njegove pomne analize postaje vidljivo da smeđa čarapa u prozi Woolfove funkcionira kao rekvizit kojim se spretno predočuju misli i osjećaje pripovjedačice, ali i karakterne osobine svih drugih likova. S tim u vezi posebno je zanimljivo da upravo tako predstavljenom predmetnošću

43 Derrida J., Recht auf Einsicht, Beč 1997, str. 6.

44 Usp. Calvino I., Lezioni americane. Sei proposte per il prossimo millennio, Milano 1995, str. 91.

45 Derrida J., Recht auf Einsicht, Beč 1997, str. 6. 


\section{BERNARDA KATUŠIĆ}

autorica inaugurira pripovjedne strategije karakteristične za modernu prozu. ${ }^{46}$

Kad je riječ o intermedijalnim prožimanjima, sama fotografija u književnom tekstu često ne funkcionira samo kao vizualna sukreatorica verbalnog univerzuma, nego kao i svojevrstan “čarobni” predmet-detalj, ključni rekvizit književnih strategija, kojemu je, iako nije eksplicitno predočen, nego tek zaodjenut u riječi, dodijeljena nova estetska funkcija. Na koji je način fotografija kao takav predmet predstavljena u postmodernoj prozi, pokazat ćemo na primjeru romana Dubravke Ugrešić Muzej bezuvjetne predaje (1997).

\section{Slikovno prikazan anđeo}

Tekst Dubravke Ugrešić Muzej bezuvjetne predaje sastavljen je iz heterogene građe u koju su međusobno upleteni disparatni narativni segmenti. ${ }^{47}$ Znakovito naslovljen prvi dio Poetika obiteljskog albuma ${ }^{48}$ ujedinjuje svojim neobičnim estetskim konceptom kolažnog albuma rasute diskurzivne segmente. Slično fotografijama, međusobno nepoznate osobe koje nisu ni u kakvoj uzajamnoj vezi, na različitim mjestima i u različito vrijeme pripovijedaju, tehnikom sjećanja, listajući svoje obiteljske albume, ulomke iz vlastitih života. Različite priče, ujedinjene posredovanjem različitih fotografija, okupljaju zasebne diskurzivne fragmente i sugeriraju, poput motivskih okidača, povratak prošlih vremena, čineći tako jedinstveni kolažni verbalni album. U svakoj mini-priči verbalno predstavljena snimka funkcionira kao poetski rekvizit kojim se ovjeravaju osobni protokoli sjećanja. No na razini narativne cjeline poetiku sjećanja nadilazi „nevidljiva“ fotografija koja - usprkos tome što je, poput ostalih fotografija, tek verbalno artikulirana - postaje osviještenom narativnom sponom, presjekom i sintezom stvarnoga i fiktivnoga, nefunkcionalnim estetskim predmetom koji autorica metatekstualno slaže i razlaže lucidno, promišljajući odnos stvarnosti i fikcije. Navedeno metatekstualno, ironično propitivanje fotografske estetike, za fotomedij tipično istovremeno autentično

46 Usp. Auerbach E., Mimesis: dargestellte Wirklichkeit in den abendländischen Literaturen, Tübingen 1994.

47 Već samim naslovom i podnaslovima brojnih zasebnih narativnih segmenata naznačuje se tematska i strukturna neujednačenost. Tekst je podijeljen u šest poglavlja: „Umorna sam“, „Kućni muzej“, „,Dobar dan“, „Arhiv: Šest priča s diskretnim motivom anđela koji napušta prostoriju“, „Što je umjetnost?“ „Grupna fotografija“, „,Gdje sam?“", koji su podijeljeni u mnogo daljnjih potpoglavlja (,Poetika obiteljskog albuma“, „Bilježnica s cvjetnim koricama“, „Dječje jaje“ itd). Usp. Ugrešić D., Muzej bezuvjetne predaje, Amsterdam 1997.

48 Usp. Isto, str. 27. 


\section{BERNARDA KATUŠIĆ}

prikazivanje i izobličavanje realnog ${ }^{49}$ još je očitije u posljednjem odjeljku romana s indikativnim naslovom Zajednička fotografija.

U finalnoj narativnoj impostaciji, za razliku od inicijalne, tehnička slika neočekivano razgrađuje mnogobrojne jednolinijski postavljene fikcijske elemente stavljajući poetski vješto znak pitanja na njihovu tematsku i strukturalnu cjelovitost i značenje. Završna sekvenca predstavlja banalnu svakodnevnu situaciju „ženskog trača”, kakve već dobro poznajemo iz prijašnjeg autoričina opusa. Jednog običnog poslijepodneva, pri nevezanu razgovoru i kartanju iz razbibrige pet bivših studentica u srednjim godinama, u ugodnu sobu prosječnog stambenog zagrebačkog bloka, nenajavljen, dolijeće anđeo na bijelim krilima.

Odmah nakon nepretenciozna dolaska neobičan se gost nenametljivo i skladno uvlači u razdragano žensko društvance i, ne zbunjujući nikoga osim čitatelja, postaje središtem „beznačajna" razgovora. Suptilno proračunata banalizacija nemogućega ne samo da iznenađuje čitatelja nego i bitno prestrojava cijelu narativnu intenciju, latentno okrećući ustaljene suprotnosti sakralnog i banalnog, te stvarnog i nestvarnog. Međutim, kulminacijska točka naznačena nesuglasja banalizacije nemogućeg ne događa se u trenutku kada je nezvani gost ulaskom u sobu ostavio ravnodušnim ,svakodnevne“ zagrebačke protagonistice i začuđene čitatelje, nego paradoksalno u trenutku kada je najavio svoj odlazak, a svih je pet dama u istom hipu posegnulo za fotoaparatom, kako bi se dokumentirao i ovjekovječio neobičan susret. Opirući se tehnikama najsavršenije reprodukcije stvarnosnog, željena fotografija nebeskog posjetitelja ne uspijeva. Naime aktericama ne uspjeva razviti fotografiju standardiziranim mehanizmima pa njezin sadržaj ostaje potpuno „nevidljiv” likovima, ali i pripovjedačici i čitatelju, zabilježen tek u sjećanju aktera, oživljen u imaginaciji čitatelja. Tako „nepostojeća” verbalizirana slika, metaforizirana metonimija nepostojećeg anđela s bijelim krilima, postaje naracijskim ishodištem ne samo fabularnog tijeka nego i književnim rekvizitom, fiktivnim predmetom ironijskog obrata vjekovne literarne žudnje prikazivanja neprikazivog.

Kao posljedica navedenog procesa intermedijalnog prožimanja književnost se više ne poima kao zaseban fikcionalni svijet, koncipiran više ili manje prema modelu iskustvene stvarnosti. Naime, u (inter)medijalno oblikovanome estetskom procesu, prirodni zakoni ostaju prividno netaknuti, a zbilja se više metaforički ne apstrahira, distancira i sažima, kao što je to bio slučaj

49 Usp. Barthes R., Die helle Kammer, Frankfurt am Main 1989, str. 13, i Derrida J., Die Tode von Roland Barthes, Berlin 1987, str. 35. 


\section{BERNARDA KATUŠIĆ}

u ,tradicionalnoj“ književnosti, nego se u vlastitome medijskom tijelu izravno integrira, registrira i simulira. U tako medijaliziranome svijetu, fikcionalan čin više nije u metaforičkome suglasju sa stvarnošću, odnosno književne strategije više nisu usmjerene na to da izobliče odgovarajući kategorijalni okvir „prvotne“ stvarnosti. Drugim riječima, kategorije vremena i prostora više se metaforički i figurativno ne rastežu, skupljaju, usporavaju, ubrzavaju ili preskaču, a protagonisti se više ne prožimaju niti umnožavaju. U (inter)medijalnim estetskim artefaktima, književne radnje nisu realizirane kao oprečni polariteti između stvarnosne i pjesničke logike, nego funkcioniraju kao osebujno njihalo, koje se njiše u nepredviđenom smjeru, postulirajući ujedno dvostruku logiku: logiku stvarnosti i logiku pjesništva, stvarajući tako zaseban, „drugotni“" svijet. Budući da književne strategije u medijskoj fikciji, suprotno "klasičnoj književnosti”, više ne funkcioniraju kao pol protivan stvarnosti, nego kao svojevrstan međuprostor stvarnosti, tako (inter)medijalno oblikovane estetske procese moguće pojmiti i kao svojevrsnu „fikcionalnu herezu“ ${ }^{\text {“50 }}$, koja stvarnosnu i fikcionalnu logiku istodobno uspostavlja i narušava.

\section{LITERATURA:}

Auerbach E., Mimesis: dargestellte Wirklichkeit in den abendländischen Literaturen, Tübingen 1994 [1946]

Barthes R., Die helle Kammer, Frankfurt am Main 1989.

Barthes R., Die strukturalistische Tätigkeit, u: Kursbuch 5, 1966, str. 190-196.

Baudrillard J., Fotografien 1985-1998, Ausstellung, Graz 1999.

Baudry J. L., Ideologische Effekte erzeugt vom Basisapparat, u: Der kinematographische Apparat, Geschichte und Gegenwart einer interdisziplinären Debatte, priredio Riesinger R. F., Münster 2003, str. $27-41$.

Benjamin W., Das Kunstwerk im Zeitalter seiner technischen Reproduzierbarkeit, Frankfurt am Main 1963.

Biti V., Pojmovnik suvremene književne teorije, Zagreb 1997.

Calvino I., Lezioni americane. Sei proposte per il prossimo millennio, Milano 1995.

Čorak Ž., Krhotine, Zagreb 1991.

Derrida J., Die Tode von Roland Barthes, Berlin 1987.

Derrida J., Recht auf Einsicht, Beč 1997.

50 Usp. Lachmann R., Exkurs: Anmerkung zur Phantastik, u: Einführung in die Literaturwissenschaft, priredio Pechlivanos M., Stuttgart / Weimar 2004, str. 224. 


\title{
BERNARDA KATUŠIĆ
}

Faulstich W., Medienwissenschaft, Stuttgart 2004.

Lachmann R., Exkurs: Anmerkung zur Phantastik, u: Einführung in die Literaturwissenschaft, priredio, Pechlivanos M., Stuttgart / Weimar 2004, str. 224-229.

Lommel M., Dispositiv, u: Medientheorie, Medienwissenschaft, Metzler Lexikon, priredio Schanze H., Stuttgart 2002, str. 65-67.

McLuhan M., The medium is the massage, New York 1967.

McLuhan M., Die magischen Kanäle, Düsseldorf / Wien 1968 [1964].

Paech J., Intermedialität. Mediales Differenzial und transformative Figurationen, u. Intermedialität, Theorie und Praxis eines interdisziplinären Forschungsgebietes, priredio Helbig J., Berlin 1998, str. 14-31.

Schanze Vorwort H., u: Medientheorie, Medienwissenschaft, Metzler Lexikon, priredio Schanze H., Stuttgart 2002, str. 5-8.

Sontag S., Über Fotografie, Frankfurt am Main 2002. [1977]

Ugrešić D., Muzej bezuvjetne predaje, Amsterdam 1997.

Vrkljan I., O biografiji, Zagreb 1987.

Zima V. P., Ästhetik, Wissenschaft und ,wechselseitige Erhellung der Künste", Einleitung, u: Literatur intermedial. Musik-MalereiPhotographie - Film, priredio Zima V. P., Darmstadt 1995, str. 1-31.

Bernarda Katušić

University in Wien, Institute for Slavic Studies, Austria

\section{MEDIA GLOBALIZATION}

\begin{abstract}
Starting from intertwining relations of the two media - photography and literature - this article is an attempt at describing how ubiquitous processes of media globalization actually reflect on some esthtetic facts. The thesis is supported by analysis of three narratives from recent Croatian literature: O biografiji (1987) by Irena Vrkljan, Krhotine (1991) by Željka Čorak and Muzej bezuvjetne predaje (1997) by Dubravka Ugrešić.
\end{abstract}

Key words: medium, literature, photography, Vrkljan, Čorak, Ugrešić 